\title{
Assessing Groundwater Availability in the Northern Atlantic Coastal Plain Aquifer System
}

\section{Nationwide Assessment of Groundwater Availability}

The U.S. Geological Survey's Groundwater Resources Program is conducting an assessment of groundwater availability throughout the United States to gain a better understanding of the status of the Nation's groundwater resources and how changes in land use, water use, and climate may affect those resources. The goal of this National assessment is to improve our ability to forecast water availability for future economic and environmental uses. Assessments will be completed for the Nation's principal aquifer systems to help characterize how much water is currently available, how water availability is changing, and how much water we can expect to have in the future (Reilly and others, 2008).

The concept of groundwater availability is more than just how much water can be pumped from any given aquifer. Groundwater availability is a function of many factors, including the quantity and quality of water and the laws, regulations, economics, and environmental factors that control its use. The primary objective of the Northern Atlantic Coastal Plain groundwateravailability study is to identify spatial and temporal changes in the overall water budget by more fully determining the natural and human processes that control how water enters, moves through, and leaves the groundwater system. Development of tools such as numerical models can help hydrologists gain an understanding of this groundwater system, allowing forecasts to be made about the response of this system to natural and human stresses, and water quality and ecosystem health to be analyzed, throughout the region.

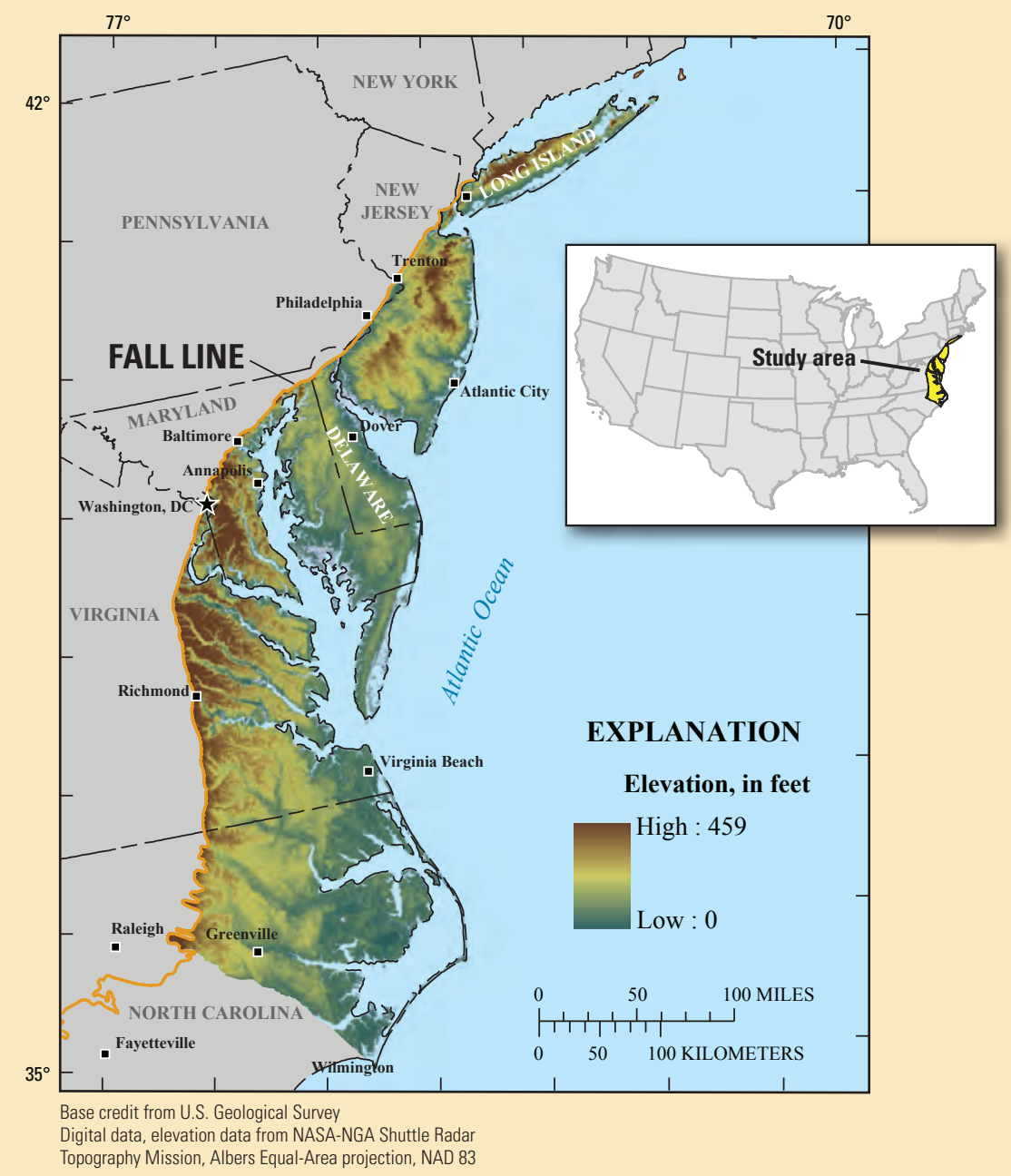

Figure 1. Location of the Northern Atlantic Coastal Plain aquifer system, eastern United States.

\section{The Importance of Groundwater in the Northern Atlantic Coastal Plain}

The Northern Atlantic Coastal Plain (NACP) occupies a land area of approximately 34,000 square miles along the eastern seaboard of the United States from Long Island, N.Y., southward to the northern portion of North Carolina (fig. 1). This area is underlain by a seaward-dipping wedge of sediments comprising clay, silt, and sand and gravel (fig. 2). This sedimentary wedge forms a complex groundwater system in which the sands and gravels function as confined aquifers, and the silts and clays function as confining units. The confined aquifers of the NACP constitute a major source of water for public and domestic supply, as well as a vital source of freshwater for industrial and agricultural uses throughout the region. 


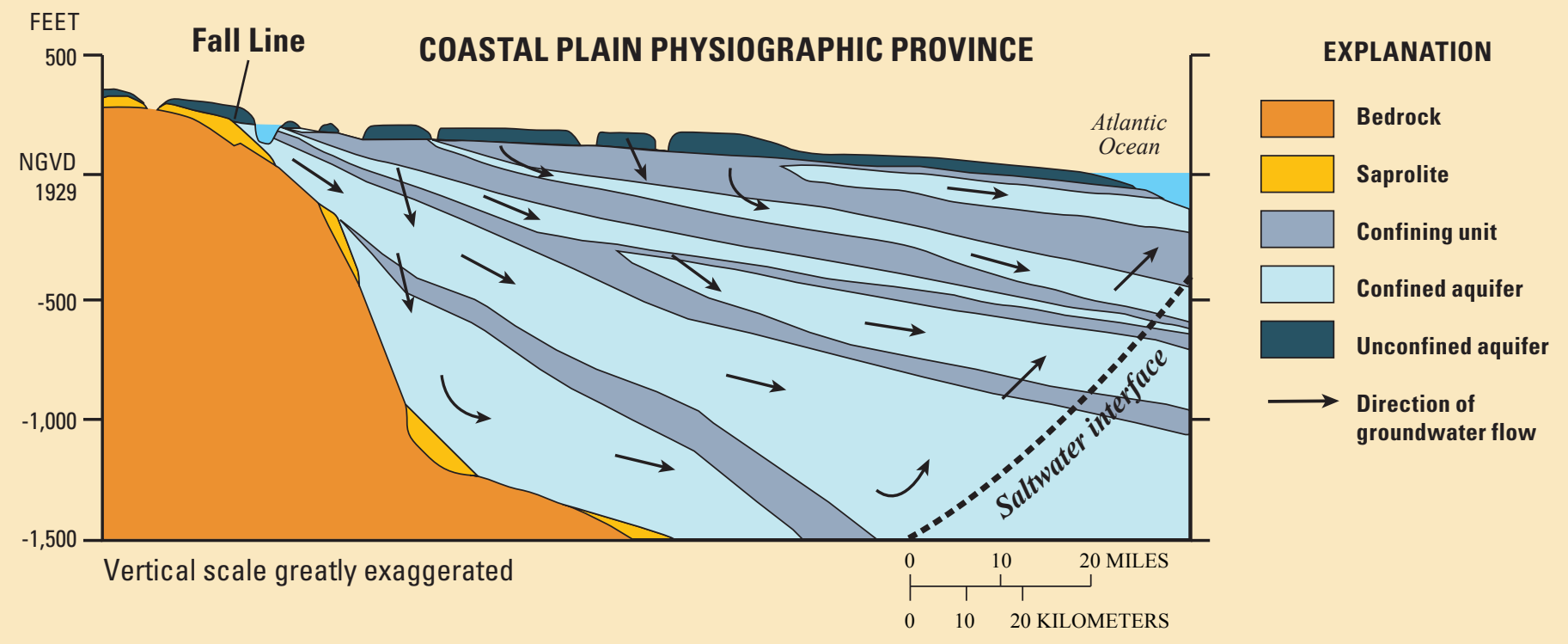

Figure 2. Schematic cross section of the Northern Atlantic Coastal Plain aquifer system (modified from Martin, 1998).

Substantial withdrawals of groundwater from the NACP aquifer system had begun by the late 1800s. By 1900 about 100 million gallons per day (Mgal/d) of water was being pumped from the NACP with about half the total from western Long Island for water supply for New York City. Groundwater withdrawals have increased steadily throughout the NACP since then; by 1980 , total groundwater withdrawals were estimated to be about 1,200 Mgal/d. Between 1980 and 2005, the population increased by about 29 percent from 21 million to approximately 27 million, whereas groundwater withdrawals increased by about 50 percent to about 1,800 Mgal/d (Forstall, 1996; Kenny and others, 2009). If the per capita rate of drinking water consumption is assumed to have remained the same during the period 1980-2005, this increase in withdrawals illustrates the importance of this vital resource for other uses besides simply being a source of fresh drinking water.

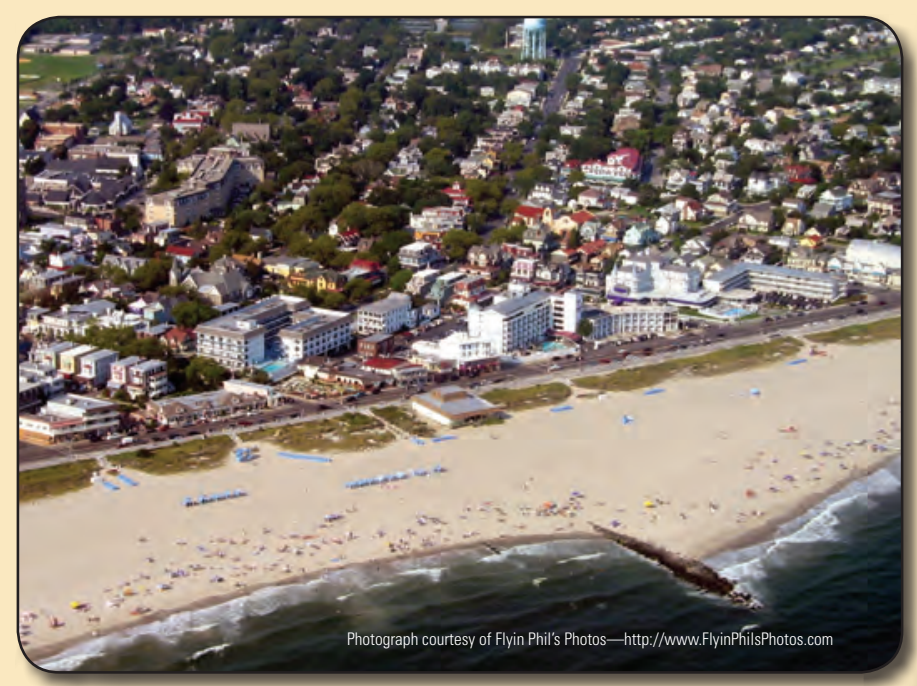

Cape May, New Jersey

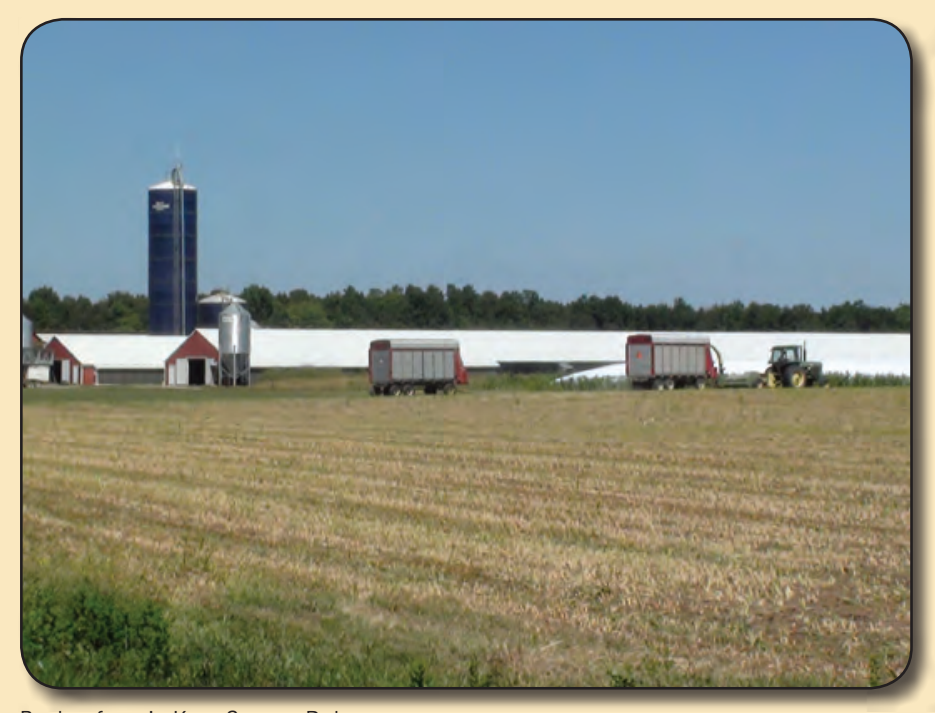

Poultry farm in Kent County, Delaware

In response to the extensive development and increased withdrawals throughout the region, water levels in many of the confined NACP aquifers have been declining by up to 2 feet ( $\mathrm{ft}$ ) per year, resulting in total declines of tens to hundreds of feet from their predevelopment levels (figs. 3 and 4) (DePaul and others, 2008). In some areas, such as southeastern Virginia, these declines are greater than $100 \mathrm{ft}$, resulting in water-level altitudes of more than $100 \mathrm{ft}$ below the mean sea-level elevation of 1929 (NGVD 29).

Water-resources management in the NACP creates hydrologic challenges beyond those imposed by the competing local domestic, industrial, agricultural, and environmental demands for water. This aquifer system extends across six State boundaries, which are typically used by water-resource managers in planning and protection efforts. As waterlevel declines extend under major coastal waters, such as the tidal portion of the Potomac River and Delaware Bay 


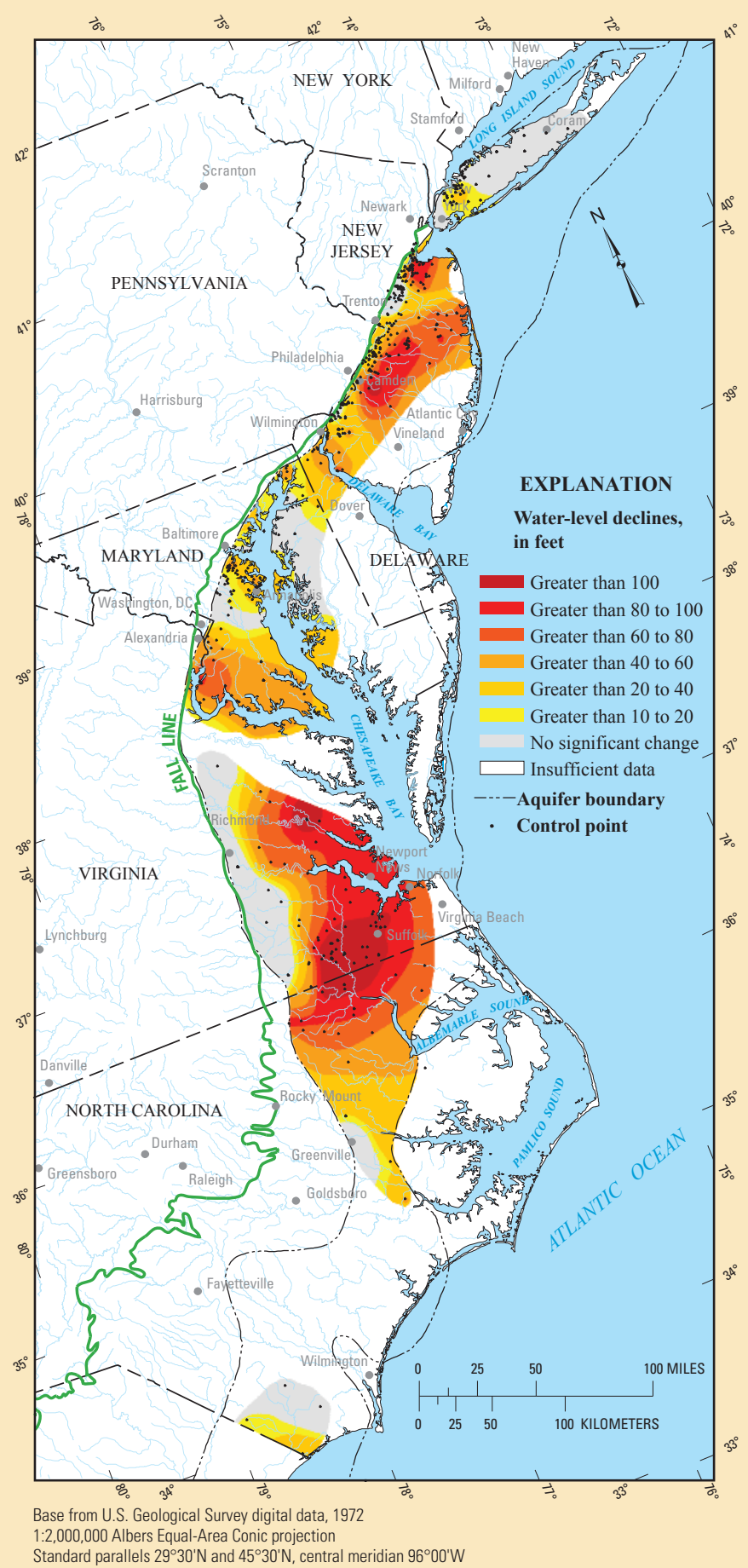

Figure 3. Estimated water-level changes in the Middle Potomac aquifer from predevelopment to 1980 (modified from DePaul and others, 2008).

and across State lines (fig. 3), the potential for interstate aquifer-management issues and the need for a comprehensive regional assessment of the groundwater availability of this aquifer system will likely increase. Regional assessments of groundwater availability, such as those conducted by the USGS Groundwater Resources Program, provide consistent and integrated information that is useful to those who use and manage the resource across political boundaries at the State and local levels (Reilly and others, 2008).

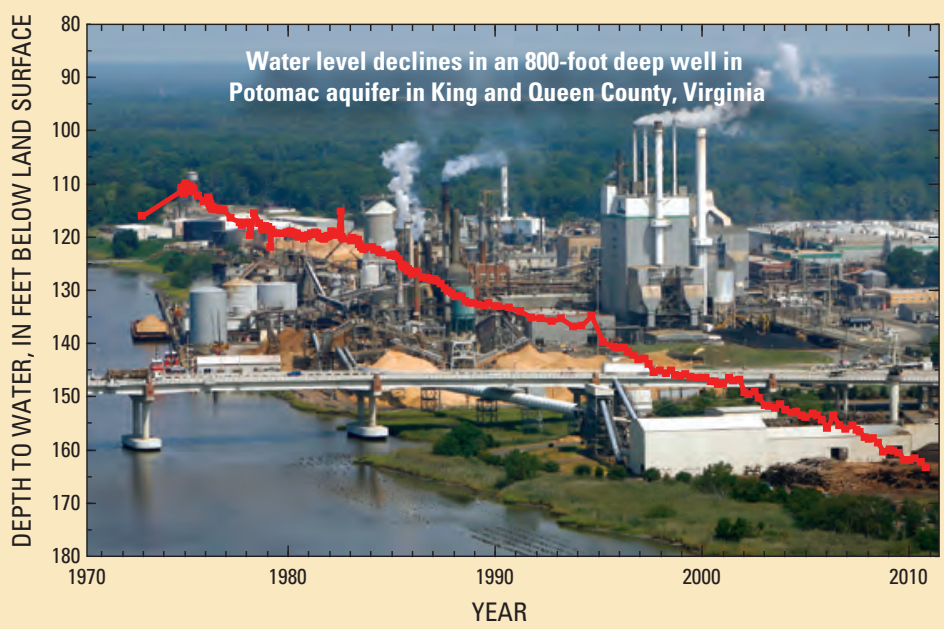

Figure 4. Industrial users such as paper mills account for a large portion of groundwater withdrawals in the Virginia Coastal Plain. (Photograph courtesy of the Richmond Times-Dispatch.)

\section{Groundwater-Availability Assessment}

USGS scientists will describe the hydrogeologic framework and quantify water-use and water-budget components (for example, recharge, withdrawals, evapotranspiration, groundwater discharge, and storage) of the aquifer system. Numerical models will be developed to forecast the effects of future groundwater development in the NACP aquifer system and to evaluate the adequacy of long-term monitoring networks to ensure that these data-collection efforts are designed properly to record potential changes in hydrologic conditions throughout the region.

\section{Hydrogeologic Conditions}

Numerous hydrogeologic data-collection efforts completed since the last regional assessment of the NACP aquifer system (Trapp and Meisler, 1992) have led to significant but generally disparate refinements of the hydrostratigraphic framework and hydrologic budgets throughout the region. These recent studies have provided local-scale improvements in the understanding of the groundwater-flow system, but the information obtained from these studies has not been synthesized into a regional hydrogeologic perspective. Synthesis of these hydrogeologic data-collection efforts into an internally consistent framework is needed to develop tools such as numerical models that can be used to forecast effects of future changes in water availability in the NACP.

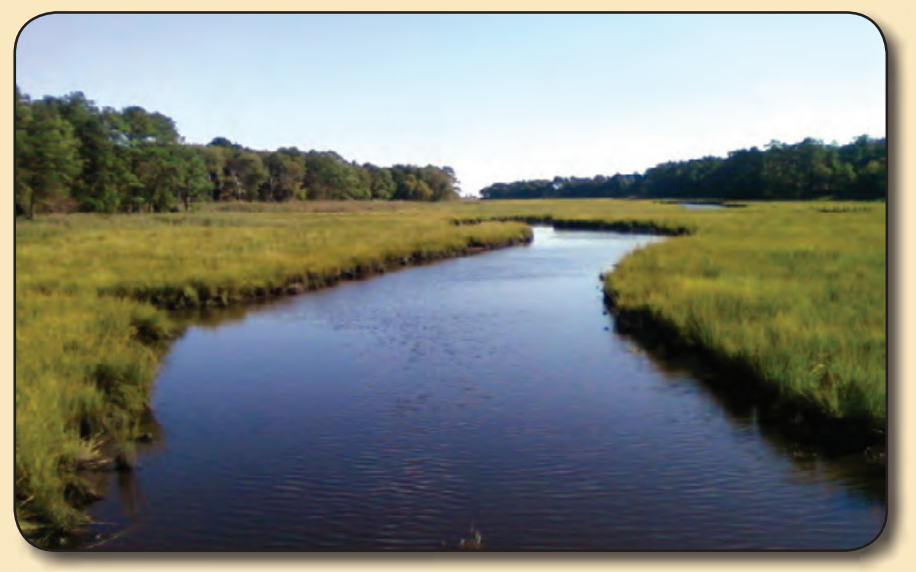

Tidal creek in Sussex County, Delaware 


\section{Numerical Models as Tools for Assessing Groundwater Availability}

Numerical models provide a means to synthesize existing hydrogeologic information into an internally consistent mathematical representation of a real system or process and thus are useful tools for testing and improving conceptual models of groundwater-flow systems (Konikow and Reilly, 1999). The groundwater-flow model of the NACP will incorporate the latest knowledge of the hydrogeology of the aquifer system and withdrawal data collected as part of this study.

With this model, it will be possible to simulate the changes that occurred in the past and then forecast future changes that may occur within the aquifer system - such as changes in water levels and aquifer storage - caused by pumping, landuse changes, and the effects of climate variability and change. A well constructed regional groundwater model will help local, State, and Federal agencies (1) assess the major inflows and outflows to the regional aquifer system; (2) understand, forecast, and manage groundwater depletion from changes in withdrawals; (3) estimate the effects of climate change on groundwater resources; (4) evaluate and refine existing long-term monitoring networks; and (5) assess the effects of proposed water-management decisions.

\section{Vital Role of Partnerships}

Multiple State and Federal agencies and nongovernmental organizations have responsibilities or interests in managing and protecting the groundwater resources of the Northern Atlantic Coastal Plain aquifer system. The USGS groundwateravailability study team is collaborating with many of these agencies and organizations to build a better understanding of the region's water resources. This knowledge will help provide input for developing tools to better understand the aquifer and to make more informed decisions about the management of the groundwater resources of the Northern Atlantic Coastal Plain aquifer system.

\section{Selected References}

DePaul, V.T., Rice, D.E., and Zapecza, O.S., 2008, Water-level changes in aquifers of the Atlantic Coastal Plain, predevelopment to 2000:

U.S. Geological Survey Scientific Investigations Report 2007-5247, 88 p. (Also available at http://pubs.usgs.gov/sir/2007/5247.)

Forstall, R.L., 1996, Population of states and counties of the United States-1790 to 1990, from the twenty-one decennial censuses: U.S. Bureau of the Census, Washington, D.C.

Kenny, J.F., Barber, N.L., Hutson, S.S., Linsey, K.S., Lovelace, J.K., Maupin, M.A., 2009, Estimated use of water in the United States in 2005: U.S. Geological Survey Circular 1344, 52 p. (Also available at http://pubs.usgs.gov/circ/1344.)

Konikow, L.F., and Reilly, T.E., 1999, Groundwater modeling, in Delleur, J.W., ed., The handbook of groundwater engineering: Boca Raton, Fla., CRC Press, 40 p.

Martin, Mary, 1998, Ground-water flow in the New Jersey Coastal Plain: U.S. Geological Survey Professional Paper 1404-H. (Also available at http://pubs.er.usgs.gov/publication/pp1404H.)

Reilly, T.E., Dennehy, K.F., Alley, W.M., and Cunningham, W.L., 2008, Ground-water availability in the United States: U.S. Geological Survey Circular 1323, 70 p. (Also available online at http://pubs.usgs.gov/circ/1323.)

Trapp, Henry, Jr., and Meisler, Harold, 1992, The regional aquifer system underlying the Northern Atlantic Coastal Plain in parts of North Carolina, Virginia, Maryland, Delaware, New Jersey, and New York: U.S. Geological Survey Professional Paper 1404-A, 33 p., $11 \mathrm{pls}$.

\section{By John P. Masterson, Jason P. Pope, Jack Monti Jr., and Mark R. Nardi}

For more information:

Visit the project Web site at: http://ny.water.usgs.gov/projects/NACP Or contact John P. Masterson 508-490-5028 jpmaster@usgs.gov Banner photograph courtesy of Chesapeake Bay Program 